\title{
Cellulosic ethanol hits roadblocks
}

\author{
The third of four weekly articles looks at how the financial crisis is slowing \\ efforts to commercialize next-generation ethanol.
}

\section{THE BUSINESS OF BIOFUELS}

This year was supposed to be a big year for BlueFire Ethanol. The company, based in Irvine, California, had planned to start operating its first commercial cellulosic biofuel plant by the end of the year, converting waste from a neighbouring landfill into ethanol. The refinery, located near Lancaster, California, would chew up everything from cardboard to hedge clippings and produce more than 11 million litres of biofuel a year.

But after a delay due to permit issues, BlueFire found itself facing a formidable roadblock: the global economic crunch. "It put us right in the middle of the meltdown," says chief executive Arnold Klann. With more financing still needed for construction, he says, the company has now pushed the plant's start-up date to late 2010 or early 2011.

A couple of years ago, Klann would have had reason to be optimistic. Cellulosic ethanol - a biofuel that can be produced from agricultural residue, grasses and municipal waste - was touted as superior to maize (corn) ethanol because it produces fewer greenhouse-gas emissions and does not compete with food-supply needs. In February 2007, the US Department of Energy selected BlueFire and five other companies to negotiate for up to US $\$ 385$ million in funding for commercial-scale plants. And later that year, Congress issued a federal mandate to produce 61 billion litres of cellulosic biofuels annually for transportation by 2022 .

Today, a combination of the recession, heightened investor wariness brought on by financial losses in maize ethanol and other hurdles have slowed the commercialization rush. According to ThinkEquity, an investment bank based in San Francisco, California, the United States will have the capacity to produce less than 13 million litres of cellulosic ethanol this year, and it will almost certainly fail to meet the US Environmental Protection Agency's (EPA) projection of 381 million litres of cellulosic biofuels in 2010. Two of the six companies selected by the Department of Energy to negotiate for commercial plant funding have dropped out of the programme, and several plants belonging to other companies have been delayed. The industry has "slowed down tremendously", says Sean O'Hanlon, executive director of the American Biofuels Council in Miami, Florida.

Part of the trouble began when last year's high maize prices and falling ethanol prices led to

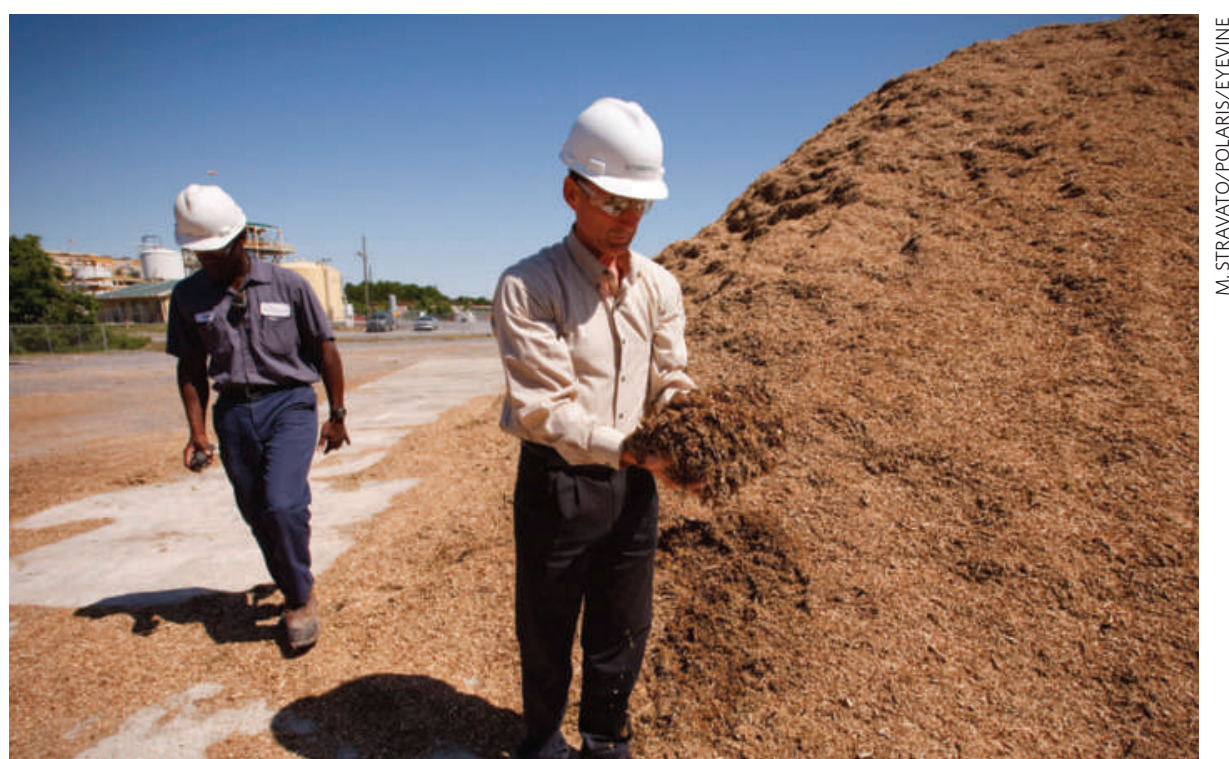

A joint venture between the fuel firms Verenium and BP aims to build a commercial biofuels plant.

several bankruptcies in the industry. Investors are now nervous about investing in cellulosic ethanol, says Laurence Alexander, an analyst at the investment bank Jefferies in New York. And the industry is rapidly approaching the regulatory 'blend wall', which says that petrol for conventional automobiles can contain no more than $10 \%$ ethanol by volume. With US maize-ethanol production expected to surpass 39 billion litres in 2009, and petrol consumption at 523 billion litres per year, cellulosic ethanol doesn't have much room to enter the market, says energy economist Wallace Tyner at Purdue University in West Lafayette, Indiana.

Other countries have continued to lag behind the United States, partly because they have fewer government incentives and support programmes. The European Union (EU), which requires that $10 \%$ of transport energy come from renewable sources by 2020 , has not set a specific goal for cellulosic fuel. China has restricted maize-ethanol production and aims to produce 2.5 billion additional litres of ethanol annually from non-food-grain sources by 2010 . But the government has not offered specific subsidies to cellulosic-ethanol producers, says John Romankiewicz, an analyst in the Beijing office of London-based New Energy Finance. "They're just waiting for the signal from the government," he says. "And they may be waiting for a while."
Companies that were expected to lead commercialization in the United States have changed or scaled back their plans. Range Fuels, based in Broomfield, Colorado, originally planned to complete the final phase of construction on a Georgia commercial plant in 2011 but has delayed that until late 2012, says chief executive David Aldous. Iogen, based in Ottawa, Canada, suspended operations on an Idaho plant to focus its resources on a possible plant in Saskatchewan, says company spokesperson Mandy Chepeka. Iogen has applied for Canadian government funding of up to Can\$200 million (US\$182 million) and is still evaluating the Saskatchewan site, she says.

\section{Industry link-ups}

Some companies are hopeful that government agencies and the oil industry will see them through the downturn. Verenium, based in Cambridge, Massachusetts, secured US $\$ 90$ million from oil company BP in August 2008, and the two companies announced a joint venture this year. The joint venture has applied for a loan guarantee from the US energy department to build a commercialscale plant in Florida, which is scheduled to begin construction in 2010 and will produce 136 million litres of ethanol a year, says Verenium chief executive Carlos Riva.

But whether cellulosic-ethanol producers 
can be profitable remains an open question. In February, researchers at Sandia National Laboratories in Livermore, California, and Albuquerque, New Mexico, and General Motors estimated that cellulosic ethanol could compete with petrol in 2030 only if oil was $\$ 90$ a barrel or higher. The price of oil is around \$65-70 a barrel.

One company looking to bring down costs is Novozymes, based in Bagsværd, Denmark. In February, Novozymes launched its first commercially available enzymes for cellulosic-ethanol production, claiming that it had reduced the cost of the enzymes by roughly half since 2008, and aims to halve the cost again by 2010 . The reductions were achieved by breeding fungal strains that produce more efficient enzymes, raising protein production levels and optimizing process design, says global biomass business development manager Cynthia Bryant. The company has partnered with the agricultural products supplier COFCO and oil refiner Sinopec in Beijing to develop a process that uses maize stalks and leaves, and it opened a research unit in Brazil this year to study the conversion of sugarcane residues to ethanol.
Others are investigating ethanol production techniques that do not require buying enzymes from other companies. Coskata, a company based in Warrenville, Illinois, in which General Motors has an undisclosed stake, relies on gasification to turn biomass into hydrogen and carbon monoxide. Proprietary bacteria then ingest the gases and produce ethanol, says chief marketing officer Wesley Bolsen. Mascoma, a start-up based in Lebanon, New Hampshire, that announced a partnership with Chevron Technology Ventures on 14 September, claims to have engineered microorganisms whose enzymes can break cellulose down into simple sugars and immediately convert those into ethanol.

Upcoming policy decisions could give cellulosic ethanol a boost. The EPA must decide by 1 December whether to increase the blend wall to $15 \%$, in response to a request submitted by advocacy group Growth Energy based in Washington DC. The industry is also waiting to see whether the EPA will put annual targets for cellulosic-biofuel production into effect on 1 January 2010 as originally proposed. In the EU, member states must submit action plans

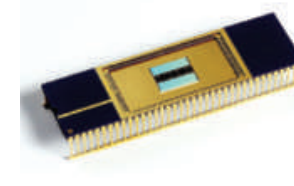

MELTING MEMORY CHIPS

Phase-change memory enters mass production. www.nature.com/news

to meet renewable-energy goals by the end of June 2010, which could include more support for cellulosic ethanol.

Attention has already begun to turn from ethanol to other cellulosic biofuels. A Perspective published in Science in August noted that biomass-derived hydrocarbon fuels, such as petrol and diesel replacements, could be more attractive because they offer higher mileage and do not require new distribution infrastructure (J. R. Regalbuto Science 325, 822-824; 2009). Once the first few cellulosic-ethanol plants have been built, people might move on to other fuels such as biobutanol or biomass-derived petrol, says Alexander. And the plant delays are giving alternative technologies a chance to catch up.

But the slowdown could also benefit those who produce cellulosic ethanol, says David Berry, a partner at venture-capital firm Flagship Ventures in Cambridge, Massachusetts. "The economic downturn has made it more difficult but also helped bring a sense of reality to the field," he says. "Companies will pull through stronger."

Roberta Kwok NEXT WEEK: BIOMASS TO LIQUIDS 